\title{
Automatické vymezení povodí na území Česka v ArcGIS Pro
} víT ŠŤOvíČEK

Klíčová slova: automatická delineace - povodí - rozvodnice - GIS - ArcHydro

\section{SOUHRN}

Manuální vymezení povodí dle rozvodnic je tradičně prováděno analýzou topografické mapy a vrstevnic. S využitím digitálních modelů reliéfu probíhá delineace povodí a řiční sítě automaticky, čímž se snižuje časová náročnost spjatá s manuálním vymezením. V tomto článku je představen samotný proces automatické delineace a nabízené modely v rámci balíčku nástrojů Arc Hydro Tools Pro, vytvořeného společností ESRI pro software ArcGIS Pro. Automatická delineace pomocí různých metod byla implementována na vybraná povodí v Česku lišící se rozlohou a nadmořskou výškou. Jako podklad sloužily digitální modely reliéfu s různým rozlišením, od velikosti buňky $2 \times 2$ m po $50 \times 50 \mathrm{~m}$. Takto vytvořená povodí byla následně porovnána s aktuální vrstvou rozvodnic 4. rádu, platnou k roku 2019. Výsledky automatické delineace u všech povodí, s výjimkou povodí v nížinách, ukazují na vysokou míru přesnosti. Automatickou delineaci Ize uplatnit nejenom jako vstup do hydrologických modelů, ale i k navazujícím analýzám povodí, např. pomocí dalších nástrojů $\checkmark$ ArcGIS Pro.

\section{ÚVOD}

Vymezení povodí je základem pro hydrologické modelování a analýzy. Tradičně je prováděno analýzou topografické mapy a vrstevnic, což je často zdlouhavý a náročný proces. S využitím digitálního modelu reliéfu (dále jen DMR), jenž reprezentuje reliéf zemského povrchu, Ize provést celý proces automaticky, čímž se výrazně snižuje jeho časová náročnost. Techniky pro automatické vymezení povodí jsou dostupné již od poloviny 80 . let a byly použity $\checkmark$ několika geoinformačních systémech (GIS) a dalších aplikacích. Vývoj těchto technik, stejně jako vznik nových DMR s vyšším rozlišením, tvoří základ pro přesnou a rychlou analýzu. Dalším důležitým faktorem je vývoj počítačové techniky, který umožňuje výkonnější a komplexní operace, jež mají být provedeny lokálně a dostatečně rychle. S tím se postupně zvětšuje poptávka po automatizovaných systémech, u nichž jsou kladeny nároky na přesné a rychle dostupné výsledky [1-3].

ArcHydro je datový model - sada nástrojů a postupů, které byly vyvinuty $\checkmark$ průběhu let a jež podporují specifické GIS implementace v oblasti vodních zdrojů. Od roku 2002 se rozširíil o více než 300 nových nástrojů z původních 30 a je hojně využíván v mnoha různých projektech celou škálou uživatelů od státních institucí přes soukromé firmy nebo školy až po běžného uživatele se zájmem o vodní zdroje [4].

Tento článek slouží jako představení procesu automatické delineace, kterou Ize provést pomocí nástrojů v balíčku Arc Hydro Tools Pro, vytvořeného společností ESRI pro software ArcGIS Pro. Samotná automatická delineace byla poté pomocí různých metod implementována na vybraná povodí v Česku lišíci se rozlohou a nadmořskou výškou, aby se ověřila její přesnost a nedostatky v různém typu reliéfu.

\section{METODIKA}

Základem ArcHydro je sada nástrojů (dále jen toolset) Hydrology, jenž je uložen $\checkmark$ balíčku nástrojů (dále jen toolbox) Spatial analyst. Rozšiření o nové nástroje a vylepšení těch stávajících přinesl nový toolbox Arc Hydro Tools. Pro přechod na ArcGIS Pro vznikl dosud nejnovější toolbox Arc Hydro Tools Pro, který byl využit pro účely tohoto článku.

Základní proces delineace a vytvoření říční sítě pomocí toolsetu Terrain Preprocessing je částečně ilustrován na obr. 1 a může být shrnut $v$ několika bodech [6]:

1. Zarovnání DMR (funkce Level DEM) - prířadí buňkám vstupního DMR stejnou hodnotu jako hodnoty v polygonech vložené vrstvy vodních útvarů.

2. Úprava DMR (DEM Reconditioning) - pretvoří reliéf „vypálením“ liniové vrstvy vodních toků pomocí metody AGREE [7], kdy je okolí vodního toku sníženo o zadané hodnoty. Tím se vytvoří zřetelnější prričný profil, který nemusí být zcela jasný u vstupního DMR z důvodu nedostatku dat o nadmořské výšce v okolí vodních toků.

3. Vyplnění depresí (Fill Sinks) - upravuje nerovnosti terénu zvýšením či snížením hodnoty buňky v závislosti na okolních buňkách tak, aby vygenerovaná ríční sít byla kontinuální.

4. Určení směru proudění (Flow Direction) - pro každou buňku určí směr proudění podle největšího rozdílu hodnot (největší sklon) mezi sousedními buňkami a vytvoří rastr (metoda D8). Dále lze vybrat metody D-Infinity nebo Multiple Flow Direction.

5. Určení akumulace proudění (Flow Accumulation) - na základě rastru Flow Direction sečte počet buněk, z nichž pritéká voda do dané buňky, a tuto výslednou hodnotu jí prirǐadí. Následně ze všech hodnot vytvoři rastr. 
6. Vygenerování ríční sítě (Stream Definition) - na základě Flow Accumulation a uživatelem zvolené prahové hodnoty (počet buněk, respektive minimální velikost povodí) vygeneruje říční sít. Všem buňkám nad prahovou hodnotou je následně prířazena hodnota 1, pod hodnotou prázdná hodnota "Null". Menší prahová hodnota vede k vytvoření hustší ríční sítě a většímu počtu dílčích povodí.

7. Segmentace říční sítě (Stream Segmentation) - rozdělí vodní toky do jednotlivých úseků (k soutoku dvou vodních toků nebo mezi jednotlivými soutoky) a přiřadí jim jedinečný identifikátor. Všechny buňky v daném úseku tak lze jednoznačně rozeznat od jiných určitým kódem "Grid Code".

8. Delineace povodí (Catchment Grid Delineation) - každé buňce přiřadí hodnotu shodující se s povodím, k němuž náleží. Tato hodnota je shodná s hodnotou jednotlivých úseků toku. Výsledný rastr se poté převede na polygonovou vrstvu pomocí funkce Catchment Polygon Processing.

9. Převedení rastru říční sítě (Drainage line Processing) - převede vygenerovaný rastr říční sítě z kroku 6 do liniové vrstvy.
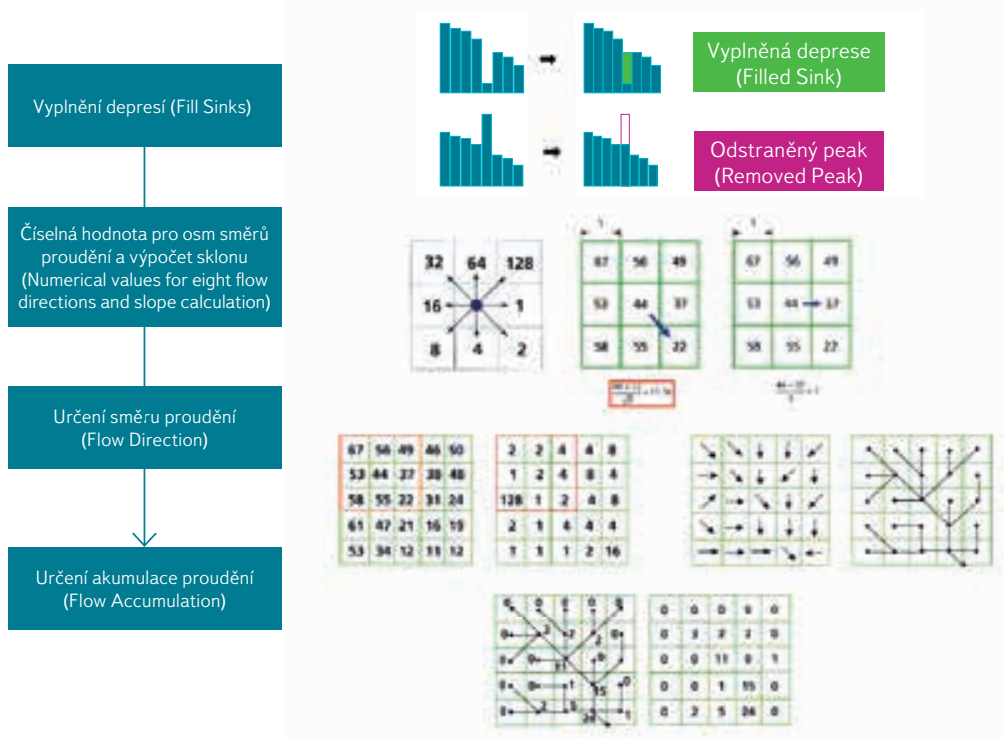

Obr. 1. Proces automatické delineace povodí [5]

Fig. 1. Automatic watershed delineation process [5]

Body 1 a 2 vyžadují vstupní polygonovou (vodní plochy), respektive liniovou (vodní toky) vrstvu, díky kterým se v následujících krocích popsané funkce mohou lišit, celý proces však funguje i bez nich.

K urychlení celého procesu Ize využít toolset Terrain Preprocessing Workflows [8], který obsahuje několik modelů, z nichž si uživatel vybírá na základě dostupných vstupních dat a typu říční sítě v daném reliéfu. Vstupní data se dělí do čtyř kategorií:

1. Uživatel má k dispozici pouze DMR bez vrstvy vodních toků a bez vymezených depresí,

2. DMR pouze s vymezenými depresemi,

3. DMR s vrstvou vodních toků i s vymezenými depresemi,

4. DMR pouze s vymezenými vodními toky.

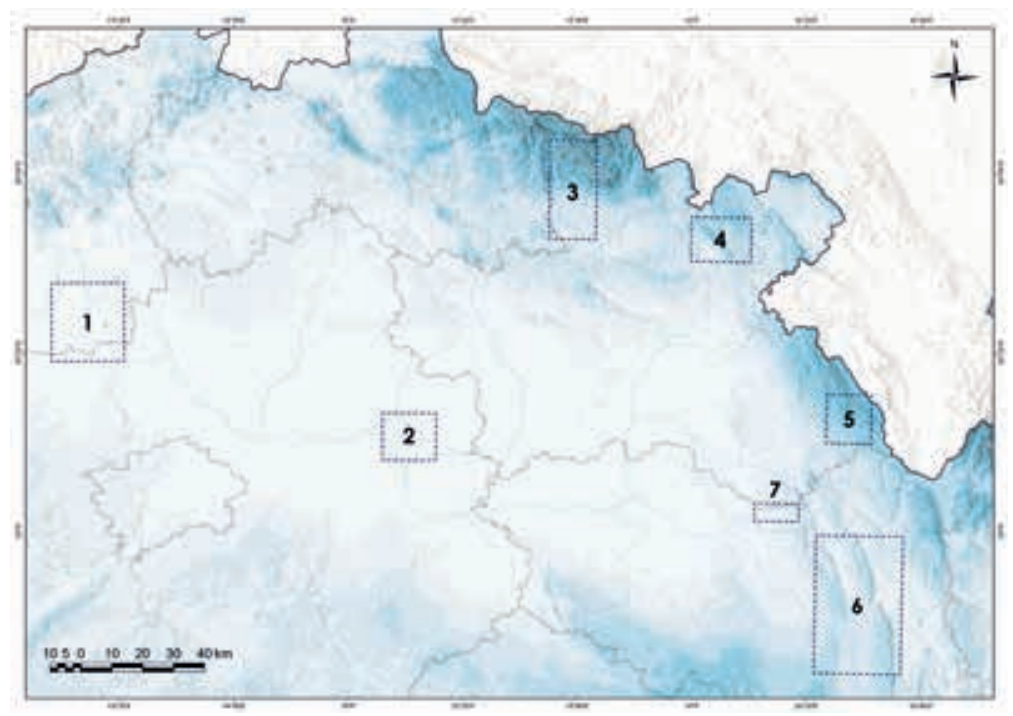

Obr. 2. Mapa vybraných povodí: 1 - Čepel, 2 - Blatnice, 3 - Malé Labe, 4 - Jívka, 5 - Říčka, 6 - Třebovka, 7 - Skořenický potok (Zdroj: DIBAVOD, ArcČR 500 a DMR 5G)

Fig. 2. Map of selected watersheds: 1 - Čepel, 2 - Blatnice, 3 - Malé Labe, 4 - Jívka,

5 - Říčka, 6 - Třebovka, 7 - Skořenický potok (Source: DIBAVOD, ArcČR 500 and DMR 5G)

Typ říční sítě se poté dělí na tři kategorie: stromovitá (dendritická), asymetrická nebo kombinace obou.

K vytvoření rozvodnic pomocí automatické delineace bylo vybráno šest povodí lišících se svou rozlohou a nadmořskou výškou a pro porovnání automatické delineace nad DMR s různým rozlišením a skutečné vrstvy rozvodnic povodí Skořenického potoka (obr. 2). Konkrétně šlo o dvojice povodí, rozlohou vždy menší a větší, nacházející se v nižinách (Blatnice, Čepel), pahorkatinách (Jívka, Třebovka) a horách (Říčka, Malé Labe). Nejprve byly vytvořeny okolo všech povodí polygony (určitý rozsah, okno, z angl. „extent", shodující se s obr. 2), v nichž byla provedena samotná delineace. Pro ni byl pro všechna povodí použit jako podklad pouze DMR 5G. Jako první model byl zvolen typ pro stromovitou rríční sít s DMR bez vrstvy vodních toků či vymezených depresí a následně druhý model s vrstvou vodních toků, jež byla vypálena do modelu reliéfu. Vrstva vodních toků byla použita z digitální báze DIBAVOD [9]. Pro znázornění odchylky mezi skutečnými a vygenerovanými rozvodnicemi byly vygenerovány polygony mezi těmito dvěma vrstvami. Podle velikosti jejich ploch se nakonec hodnotila přesnost celé delineace. Aktuální vrstva rozvodnic je ke stažení na stránkách: http://voda.chmi.cz/opv/stahnout.html.

Pro porovnání automatické delineace nad DMR s různým rozlišením a skutečné vrstvy rozvodnic v povodí Skořenického potoka bylo dohromady využito čtyř modelů reliéfu - DMR 5G, DMR 4G, DMÚ 25, dostupných ze stránek ČÚZK (https://geoportal.cuzk.cz) a ArcČR 500 dostupného ze stránek Arcdata Praha (https://www.arcdata.cz/produkty/geograficka-data/arccr-4-0) s velikostí pixelu 2, 10, 25 a 50 m. Jako model byl opět zvolen typ pro stromovitou říční sít s DMR bez vrstvy vodních toků či vymezených depresí.

\section{VÝSLEDKY A DISKUZE}

Prvním hodnoceným aspektem byl vliv rozlišení DMR na automatickou delineaci povodí. Jako testovací území bylo vybráno povodí Skořenického potoka s rozlohou 17,1 km², průměrným sklonem $3,72 \%$ a průměrnou nadmořskou výškou 361 m n. m. Z výsledných hodnot v tab. 1 je zřejmé, že se snižujícím se rozlišením DMR klesá i přesnost samotné delineace. Zatímco při využití DMR 4G je odchylka od skutečné rozvodnice větší než $4 \%$, u rozlišení $25 \times 25$ m je více než dvojnásobná a u nejnižšího rozlišení 50 ×50 m dosahuje již 12,8 \%. 
Tab. 1. Výsledky automatické delineace v povodí Skořenického potoka

Tab. 1. Results of the automatic delineation in the Skorenický potok watershed

\begin{tabular}{|c|c|c|}
\hline Rozlišení DMR [m] & Rozdíl ploch [ $\left.\mathrm{km}^{2}\right]$ & Odchylka [\%]* \\
\hline DEM resolution [m] & Area difference $\left[\mathrm{km}^{2}\right]$ & Deviation [\%] \\
\hline $2 \times 2$ & 0,87 & 5,11 \\
\hline $10 \times 10$ & 0,95 & 5,55 \\
\hline $25 \times 25$ & 1,82 & 10,66 \\
\hline $50 \times 50$ & 2,19 & 12,79 \\
\hline
\end{tabular}

*Poměr rozdilu ploch ku celkové ploše povodi

*Ratio of area difference to total watershed area

Potvrzuje se tak, že přesná delineace povodí závisí z velké části na kvalitě výchozího DMR, presněji pak na jeho rozlišení [10-12]. Detailnější pohled na rozdíl mezi vygenerovanými rozvodnicemi nabízí obr. 3. Z něho je patrné, že při užití DMR s nižším rozlišením vznikají jakési „zuby“ dané velikostí pixelu, což zabraňuje detailní a přesné delineaci.

Celková odchylka je však u tak malého povodí u všech typů DMR poměrně výrazná. V tomto případě je to zapríćiněno malou oblastí v západní části povodí s nízkým sklonem a komplikovanou říční sítí. Při automatické delineaci nedošlo k vygenerování části vodního toku, a rozvodnice tak byla vedena jiným směrem. Předejít takovéto chybě se dá pomocí vypálení skutečných vodních toků do samotného reliéfu. Pokud bychom pro ilustraci použili terén s vypálenými toky u povodí Skořenického potoka, dostali bychom celkovou odchylku u DMR 5G mírně větší než $4 \%$.

Výsledky delineace pro šest vybraných povodí znázorňuje tab. 2. Nejmenšího rozdílu bylo dosaženo u rozlohou největšího povodí Třebovky, kde odchylka (bez vypálených toků) činila pouhých 0,89\%. Nepatrně více měla obě horská povodí Řička a Malé Labe, s odchylkami 1,34 a 1,85 \%, další pahorkatinné

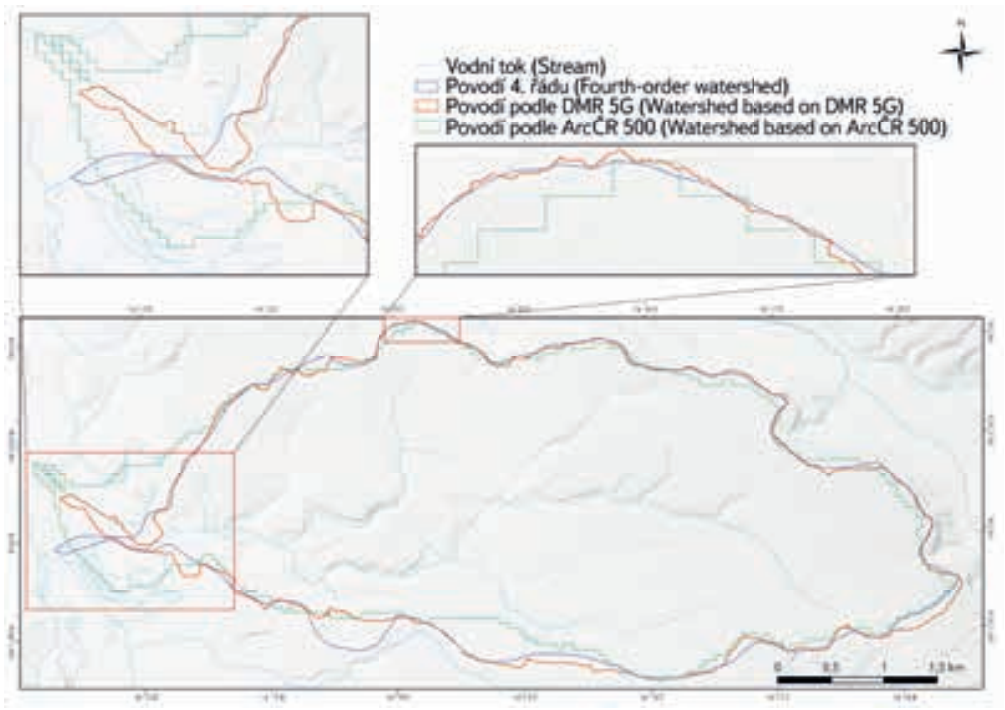

Obr. 3. Vygenerovaná povodí Skořenického potoka při využití různých digitálních modelů reliéfu

Fig. 3. Delineated watersheds of Skořenický potok using different digital elevation models

povodí Jívka mělo stále malou odchylku 2,35 \%. Nejméně přesně byla vygenerována nížinná povodí. U povodí Blatnice dosahovala odchylka 7,55 \% a u většího povodí Čepele vysokých 9,13\%.

Terén s vypálenou vrstvou vodních toků snízil odchylku u všech povodí kromě Čepele, kde naopak došlo k nárůstu o téměř $2 \%$. Vysoké odchylky u povodí Čepele, stejně jako u jiných nížinných povodí, mohou být zapríčiněny tím, že danou oblastí prochází liniový prvek (především dálnice a železniční tratě), který výrazně zasahuje do jinak rovinného terénu. Pokud je pak nadmořská výška daného prvku výrazněji pod nebo nad úrovní okolního terénu, může ji model vyhodnotit jako rozvodnici, př́padně jako samotný vodní tok, který tím zásadně mění průběh povodí, jako je tomu u povodí Čepele (obr. 4).

\section{Průměrná}

Název povodí

\section{nadmořská}

výška [m n. m.]

\section{Name \\ of watershed}

$\begin{array}{lll}\text { Average } & \text { Average } & \text { Area } \\ \text { altitude } & \text { slope }[\%] & {\left[\mathrm{km}^{2}\right]}\end{array}$

[m a.s. I.]

\begin{tabular}{|c|c|c|c|c|c|c|c|}
\hline Říčka & 740,35 & 10,76 & 33,52 & 0,45 & 0,45 & 1,34 & 1,34 \\
\hline Malé Labe & 689,51 & 12,17 & 73,36 & 1,36 & 1,21 & 1,85 & 1,65 \\
\hline Blatnice & 193,32 & 1,47 & 33,55 & 2,53 & 1,32 & 7,55 & 3,95 \\
\hline Čepel & 226,88 & 2,72 & 98,97 & 9,04 & 10,83 & 9,13 & 10,94 \\
\hline Jívka & 555,5 & 11,82 & 27,96 & 0,66 & 0,62 & 2,35 & 2,20 \\
\hline Třebovka & 476,18 & 6,14 & 195,85 & 1,74 & 1,73 & 0,89 & 0,88 \\
\hline
\end{tabular}

*Pomér rozdilu ploch ku celkové ploše povodí

*Ratio of area difference to total watershed area

$$
\text { Rozdíl ploch [km²] }
$$

Area difference $\left[\mathrm{km}^{2}\right]$

Model bez

Odchylka [\%]*

Deviation [\%]* vypálených vodních toků

Model Model bez s vypálenými vodními toky

Model without

Model with

Model without

Model with vypálených vodních toků

Model without

Model without

Model s vypálenými vodními toky

Model with burnt with burnt streams 


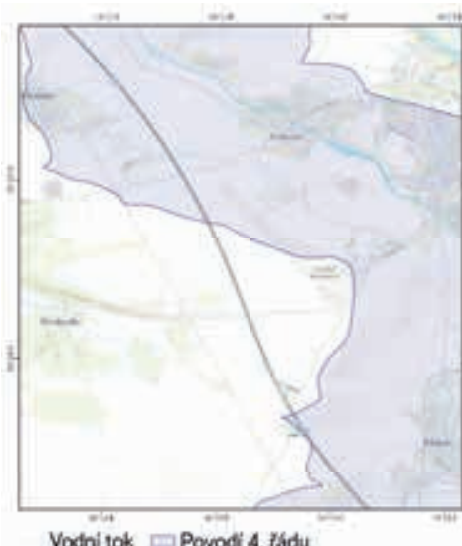

Vodni tok $\square$ Povodi 4, Fadu

(Stream) (Fourth-order watershed)

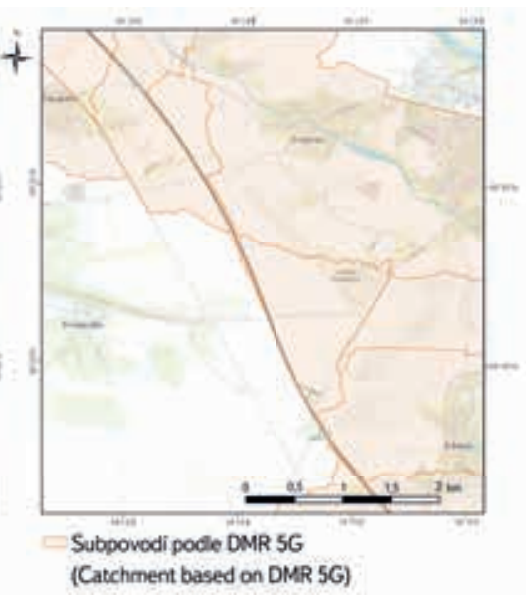

(Catchment based on DMR 5G)
Obr. 4. Vliv dálnice na automatickou delineaci povodí a subpovodí Čepele (Podkladová mapa: Esri World Topographic Map)

Fig. 4. Impact of a motorway on the automatic delineation of the Čepel watershed and catchments (Source map: Esri World Topographic Map)

Literatura [13] mimo jiné uvádí, že prvky jako umělé vodní toky, nízké hráze či velká jezera mohou tvořit významné deprese v terénu, jež mají vliv na přesnost výsledků, a to především v nižinných oblastech, říčních nivách. To má za následek vygenerování nereálné říční sítě, což je navíc limitováno rozlišením použitého DMR. K odstranění depresí se využívá funkce Fill Sinks, ovšem je otázkou, do jaké míry daný reliéf vyhladit. Na jednu stranu je určité vyhlazení potřeba, nebot se tím odstraní nepresnosti vstupního DMR a Ize tak dosáhnout realističtějšího povrchu se zachováním topografických charakteristik, na stranu druhou přiliš velké vyhlazení může změnit či odstranit skutečné (prírodní) deprese, důležité pro přesný popis reliéfu. Správné vyhlazení DMR tak v tomto prípadě vede přes dobře zvolenou prahovou hodnotu pro snížení či zvýšení depresí. Ovšem jediná zvolená hodnota nemůže ve výsledku odpovídat celému zkoumanému území, a proto je potřeba brát v úvahu záměr a rozsah celé studie [14, 15].

Ačkoli u ostatních povodí došlo vypálením vodních toků do terénu ke snížení odchylky, jednalo se ve všech případech pouze o nepatrnou změnu v řádech desetin, či dokonce setin procent, s výjimkou povodí Blatnice, kde došlo ke zpřesnění o 3,6 \%. Výsledky tak mohou napovídat, že vypálení vodních toků do terénu postrádá u některých povodí smysl, ovšem při detailnějším zkoumání výsledných rozvodnic vychází najevo, že zpřesnění se projevuje především v jednotlivých subpovodích (angl. catchments), nikoli v celém vybraném povodí (angl. watershed). Vypálení vodních toků v tomto prípadě nemá vliv na výslednou přesnost, nicméně mohlo by ovlivnit následné analýzy povodí, respektive subpovodí. Použití vrstev vodních toků tak může výrazně zvýšit přesnost při vymezování povodí, především v rovinných nížinných oblastech [16, 17].

Mezi další zpřesňující faktory Ize zařadit využití vrstvy vodních ploch, čímž se zajistí propojení říční sítě s jezery, pobřežními lagunami nebo estuáry [18]. Pro tyto účely Ize napríklad použít volně dostupnou vrstvu SRTM (Shuttle Radar Topography Mission) Water Body Dataset od USGS s rozlišením $30 \times 30$ m (https://earthexplorer.usgs.gov). Metody pro automatickou delineaci v bezodtokových oblastech při použití SRTM DEM (Digital Elevation Model) představuje např. Liu [10].

$\checkmark$ neposlední řadě může hrát roli nastavení prahové hodnoty pro vygenerování říční sítě. $V$ modelech využitých pro tuto studii je tato hodnota defaultní (automaticky vyhodnocena modelem na základě DMR). Zvolením nižší hodnoty, čímž se zahustí ríční sít, však může dojít ke zpřesnění delineace [19].

Ačkoli je v celém článku porovnávána „přesnost“ vymezení povodí, nelze brát vrstvu skutečných rozvodnic jako podklad prostý jakýchkoli chyb. Jde o vrstvu, která je pravidelně aktualizována, avšak obsahuje velké množství ploch, kde vedení rozvodnic není zcela jednoznačné. Automatická delineace naopak přesně respektuje daný reliéf a pro každý pixel jasně určí směr proudění. Na druhou stranu nedokáže správně vyhodnotit určitá specifika, jako jsou vodní toky vedené pod povrchem či uměle vybudované kanály, jež se berou $\checkmark$ potaz při manuální tvorbě rozvodnic. Výsledky je tak potřeba brát s určitou rezervou a nahlížet na ně jako na možnosti využití nástrojů ArcHydro Pro v nejnovějším zobrazení reliéfu Česka. Do budoucna by bylo vhodné udělat analýzu většího počtu povodí s rưznou rozlohou, na jinak členitém reliéfu a zjistit, jaké prahové hodnoty (pro vyplnění/úpravu depresí či hustotu rriční sítě) by ve výsledku nejlépe popsaly daný terén a daly tak základ pro co nejefektivnější automatickou delineaci. Zároveň je potřeba věnovat větší pozornost povodím v nížinách, v oblastech s rovným terénem, kde podle provedených studií dochází k největším odchylkám od skutečných rozvodnic. K vyhodnocení přesnosti delineace by následně bylo vhodné použít více hodnotících kritérií založených na tvarových či délkových charakteristikách rozvodnic. Pro ilustraci lze uvést délky rozvodnic $v$ povodí Skořenického potoka (obr. 3). Délka skutečné rozvodnice zde činí 21,2 km, vygenerované podle DMR s rozlišením $25 \times 25$ m necelých 27 km a s rozlišením $2 \times 2$ m téměř 31 km, což na první pohled neodpovídá mapě ani výsledným odchylkám. Díky vysokému rozlišení u DMR $5 \mathrm{G}$ totiž na vygenerované rozvodnici vzniká mnoho malých „zubü", které zvyšují její celkovou délku. Pokud bychom chtěli hodnotit dle tohoto kritéria, museli bychom nejdřive zvolit co nejvhodnější míru generalizace rozvodnice. Kdybychom např. tuto rozvodnici vyhladili dle funkce Smooth Line s tolerancí 100 m, byla by její výsledná délka 22,1 km, tedy jen o necelý kilometr více než délka skutečné rozvodnice.

\section{VYUŽITÍ}

Automatickou delineaci povodí Ize uplatnit především jako vstup do hydrologických modelů, např. SWAT, HBV, HEC-GeoHMS či ILWIS. Vytvořené studie se zaměřují spíše na porovnání různých metod a postupů při delineaci než na rozdíly v přesnosti mezi modely, tudiž nelze jednoznačně ríci, který model je vhodnější. Obecně se však jejich závěry shodují s výstupy této studie, a to zejména v tom, že největší rozdíly při delineaci se tvoří v oblastech nížin s rovným terénem (případně príbřežních oblastech) a přesnost delineace vysoce záleží na rozlišení vstupního DMR [20, 16, 17]. Využití ve větším měřítku Ize nalézt např́klad v Panevropské databázi řek a povodí [18], která obsahuje data o říční síti, jezerech a hranicích povodí v celé Evropě. Ta jsou vytvořena na základě DMR s rozlišením 100 m, čímž vznikají podmínky pro modelování ve středním a malém měřítku. Jako další vstupní data pro delineaci povodí a vygenerování říční sítě sloužila výšková data SRTM, odvozená vrstva pobřežní linie a vybrané prírodní deprese. V nezbytných prípadech, ve velmi rovném terénu, kdy nebylo možné jednoznačně určit průběh vodního toku podle DMR, byla využita referenční sít vodních toků. Sít vodních toků a na ni navazující povodí byla generována dle klasické metody D8 pro určení směru proudění a algoritmu dle Soilla a Gratina [21] pro určení akumulace proudění. Pro řešení problémů proudění toků v rovinatém terénu byly použity tři nové algoritmy [22] a část terénu ve směru proudění u umělých depresí byla vyříznuta, namísto aby byla samotná deprese vyplněna, čímž se zamezilo dalšímu rozšíření rovinatého terénu. Na podobné nebo další metody a algoritmy pro optimální odstranění depresí se zaměřují studie [23, 24], jež by zároveň mohly být návodem, jak zpřesnit delineaci, a daly by se aplikovat na území vybraná v této studii.

V ČHMÚ momentálně probíhá aktualizace rozvodnic nad DMR 5G. Editace probíhá manuálně v aplikaci ArcGIS Pro s vrstvou vodních toků ZABAGED a s využitím automaticky generovaných vrstevnic a vrstevnic odvozených a poskytnutých z ČÚZK [25]. Zároveň mohou editoři využít toolbox HydroDEM, podle něhož se vygenerují rozvodnice automaticky. Automatická delineace se tak v tomto prípadě využívá především jako pomocný nástroj, a to zejména $\checkmark$ rovinných oblastech nižin, kde není vedení rozvodnic tak jasné jako u povodí s větším sklonem. 


\section{ZÁVĚR}

V tomto článku byla představena možnost automatické delineace povodí a řiční sítě pomocí nástrojů v balíčku Arc Hydro Tool Pro v prostředí ArcGIS Pro. Byl popsán samotný proces automatické delineace a v rámci zhodnocení její funkčnosti a přesnosti byla aplikována na vybraná povodí v České republice. Nejpřesněji byla vygenerována povodí v horských a pahorkatinných oblastech (odchylka velikosti povodí od skutečných rozvodnic do max. 2,4 \%), nejméně pak v oblasti nížin. Výsledky korespondují s dosavadními výsledky dalších studií, u nichž k největším odchylkám dochází taktéž v nížinných oblastech s rovným terénem. Dále byla potvrzena i snižující se presnost delineace s nižším rozlišením vstupního DMR. Byly diskutovány možné způsoby úprav DMR a změny v postupu vygenerování rozvodnic za účelem zpřesnění delineace. $V$ rámci dalšího výzkumu bylo navrženo aplikovat automatickou delineaci na větší počet povodí se zaměřením na nízinné oblasti. Výslednou přesnost by mohla ovlivnit zejména úprava DMR - jak vstupní vrstvou vodních ploch, tak i různými možnostmi úpravy depresí. Automatickou delineaci pomocí nástrojů v baličku Arc Hydro Tool Pro společně s DMR o dostatečně vysokém rozlišení pro daný účel studie tak Ize doporučit jako výkonný a dostatečně přesný nástroj.

\section{Literatura}

[1] DJOKIC, D., YE, Z. DEM Preprocessing for Efficient Watershed Delineation [on-line] In: Proceedings of the 19 $9^{\text {th }}$ Esri Users Conference, San Diego, CA. 1999. Dostupné z: https://proceedings.esri.com/library/ userconf/proc99/proceed/papers/pap676/p676.htm

[2] GARBRECHT, J., MARTZ L. W. Digital Elevation Model Issues in Water Resources Modeling [on-line] In: Proceedings of the $19^{\text {th }}$ Esri Users Conference, San Diego, CA. 1999. Dostupné z: https://proceedings.esri. com/library/userconf/proc99/proceed/papers/pap866/p866.htm

[3] MERWADE, V. Terrain Processing Using ArcHydro/GeoHMS [on-line]. School of Civil Engineering, Purdue University, 2019. Dostupné z: https://web.ics.purdue.edu/ vmerwade/education/terrain_ processing.pdf

[4] DJOKIC, D. Arc Hydro in ArcGIS Pro: The Next Generation of Tools for Water Resources, In: Esri Federal GIS Conference Proceedings, Washington D. C. 2020. Dostupné z: https://www.esri.com/content/dam/ esrisites/en-us/events/conferences/2020/federal-gis/archydro-in-arcgis-pro-the-next-generationof-tools-for-water-resources.pd

[5] MAIDMENT, D. R. Arc Hydro: GIS for Water Resources. Redlans, Calif.: ASRI Press, 2002. ISBN 1589480341.

[6] ESRI. Arc Hydro Tools v2.0 - Tutorial [on-line]. 2011, s. 184. Dostupné z: http://downloads.esri.com/ archydro/archydro/Tutorial

[7] FERDI, H. AGREE - DEM Surface Reconditioning Systém [on-line]. 1997. Dostupné z: https://www. ce.utexas.edu/prof/maidment/GISHYDRO/ferdi/research/agree/agree.html

[8] ESRI. Arc Hydro: Overview of Terrain Preprocessing Workflows [on-line]. 2019, s. 18. Dostupné z: https:// www.esri.com/content/dam/esrisites/en-us/media/whitepaper/archydro-overviewofterrainproces singworkflows.pdf

[9] DIBAVOD - Digitálníbáze vodohospodářských dat [on-line]. Dostupné z: http://www.dibavod.cz

[10] LIU, K., SONG, CH., KE, L., JIANG, L., MA, R. Automatic Watershed Delineation in the Tibetan Endorheic Basin. A Lake-Oriented Approach Based on Digital Elevation Models. Geomorphology [on-line]. 2020, č. 358. ISSN 0169555X. Dostupné z: doi: 10.1016/j.geomorph.2020.107127

[11] WILSON, J. P. Digital Terrain Modeling. Geomorphology [on-line]. 2012, 137(1), s. 107-121. ISSN 0169555X. Dostupné z: doi: 10.1016/j.geomorph.2011.03.012

[12] ALCARAZ, S. A., SANNIER, CH. C. T., VITORINO, A., DANIEL, O. Comparison of Methodologies for Automatic Generation of Limits and Drainage Networks for Hidrographic Basins. Revista Brasileira de Engenharia Agrícola e Ambiental [on-line]. 2009, 13(4), s. 369-375. ISSN 1415-4366. Dostupné z: doi: $10.1590 /$ S1415-43662009000400001

[13] LI, L., YANG, J., WU, J. A Method of Watershed Delineation for Flat Terrain Using Sentinel-2A Imagery and DEM: A Case Study of the Taihu Basin. ISPRS International Journal of Geo-Information [on-line]. 2019, 8(12). ISSN 2220-9964. Dostupné z: doi: 10.3390/ijgi8120528

[14] LI, S., MACMILLAN, R. A., LOBB, D. A., MCCONKEY, B. G., MOULIN, A., FRASER, W. R. Lidar DEM Error Analyses and Topographic Depression Identification in a Hummocky Landscape in the Prairie Region of Canada. Geomorphology [on-line]. 2011, 129(3-4), s. 263-275. ISSN 0169555X. Dostupné z: doi: 10.1016/j. geomorph.2011.02.020

[15] GRIMALDI, S., NARDI, F., Di BENEDETTO, F., ISTANBULLUOGLU, E., BRAS, R. L. A Physically-Based Method for Removing Pits in Digital Elevation Models. Advances in Water Resources [on-line]. 2007, 30(10), s. 2151-2158. ISSN 03091708. Dostupné z: doi: 10.1016/j.advwatres.2006.11.016
[16] RAY, L. K. Limitation of Automatic Watershed Delineation Tools in Coastal Region. Annals of GIS [on-line]. 2018, 24(4), s. 261-274. ISSN 1947-5683. Dostupné z: doi: 10.1080/19475683.2018.1526212

[17] BAKER, M. E., WELLER, D. E., JORDAN, T. E. Comparison of Automated Watershed Delineations: Effects on Land Cover Areas, Percentages, and Relationships to Nutrient Discharge. Photogrammetric Engineering and Remote Sensing. 2006, 72, s. 159-168.

[18] VOGT, J., SOILLE, P., DE JAGER, A., RIMAVICIUTE, E., MEHL, W., FOISNEAU, S., BODIS, K., DUSART, J., PARACCHINI, M., HAASTRUP P. BAMPS, C. A Pan-European River and Catchment Database. EUR 22920 EN. Luxembourg (Luxembourg): OPOCE, 2007. JRC40291

[19] LI, Z. Watershed Modeling Using Arc Hydro Based on DEMs: A Case Study in Jackpine Watershed. Environmental Systems Research [on-line]. 2014,3(1). ISSN 2193-2697. Dostupné z: doi: 10.1186/2193-2697-3-11 [20] BALASUBRAMANI, K., SARAVANABAVAN, V., KANNADSAN, K. A Comparison of Approaches for Automated Watershed Delineation: A Case Study of NagalAr Watershed. [on-line]. 2012. Dostupné z: https:// www.researchgate.net/publication/267601581_A_Comparison_of_Approaches_for_Automated_ Watershed_Delineation_A_Case_study_of_NagalAr_Watershed

[21] SOILLE, P., GRATIN, C. An Efficient Algorithm for Drainage Network Extraction on DEMs. Journal of Visual Communication and Image Representation. 1994, 5, s. 181-189.

[22] SOILLE, P. Morphological Image Analysis. 2 ${ }^{\text {nd }}$ Edition. Berlin, Heidelberg, New York: Springer 2003.

[23] WANG, Y., QIN, CH., ZHU, A. Review on Algorithms of Dealing with Depressions in Grid DEM. Annals of GIS [on-line]. 2019, 25(2), s. 83-97. ISSN 1947-5683. Dostupné z: doi: 10.1080/19475683.2019.1604571

[24] JACKSON, S. Designing an Optimal Pit Removal Tool for Digital Elevation Models [on-line]. 2012, s. 11. Dostupné z: https://www.caee.utexas.edu/prof/maidment/giswr2012/TermPaper/Jackson.pdf

[25] MATULOVÁ, J., TYL, R. Aktualizace rozvodnic ČR nad digitálním modelem reliéfu $5 G$ [on-line]. Dostupné z: https://storymaps.arcgis.com/stories

\section{Autor}

\section{Bc. Vít Štovíček}

凶vit.stovicek@chmi.cz

ORCID: 0000-0002-4997-8056

Český hydrometeorologický ústav, Oddělení hydrofondu a bilancí, Praha

Příspěvek prošel lektorským řizením.

DOI: 10.46555/VTEI.2021.11.002 


\section{AUTOMATIC WATERSHED DELINEATION IN CZECH REPUBLIC USING ARCGIS PRO}

\section{ŠŤOVÍČEK, V.}

Czech Hydrometeorological Institute, Hydrology Database and Water Budget Department, Prague

Keywords: automatic delineation - watershed watershed divide - GIS - ArcHydro

Manual watershed delineation by watershed divides is traditionally performed by analysis of topographic maps and contour lines. With the availability of digital elevation models, watershed and stream delineation is performed automatically, which reduces the time spent on manual delineation. In this study, we introduce the process of automatic delineation and available models within the toolbox Arc Hydro Tool Pro, created by ESRI for ArcGIS Pro software. Automatic delineation was implemented by different methods on selected watersheds in Czech Republic, varying in area and altitude. Digital elevation models with different resolutions, from pixel size of $2 \times 2 \mathrm{~m}$ to $50 \times 50 \mathrm{~m}$, were used as the input layer. Next, these delineated watersheds were compared with the current layer of fourth-order watershed divides, valid to 2019. Results of automatic delineation in each watershed, except those in lowlands, show a high overall accuracy. Automatic delineation can be applied not only as the input to hydrological models but also to consequent watershed analysis, for example, with the use of other tools in ArcGIS Pro.

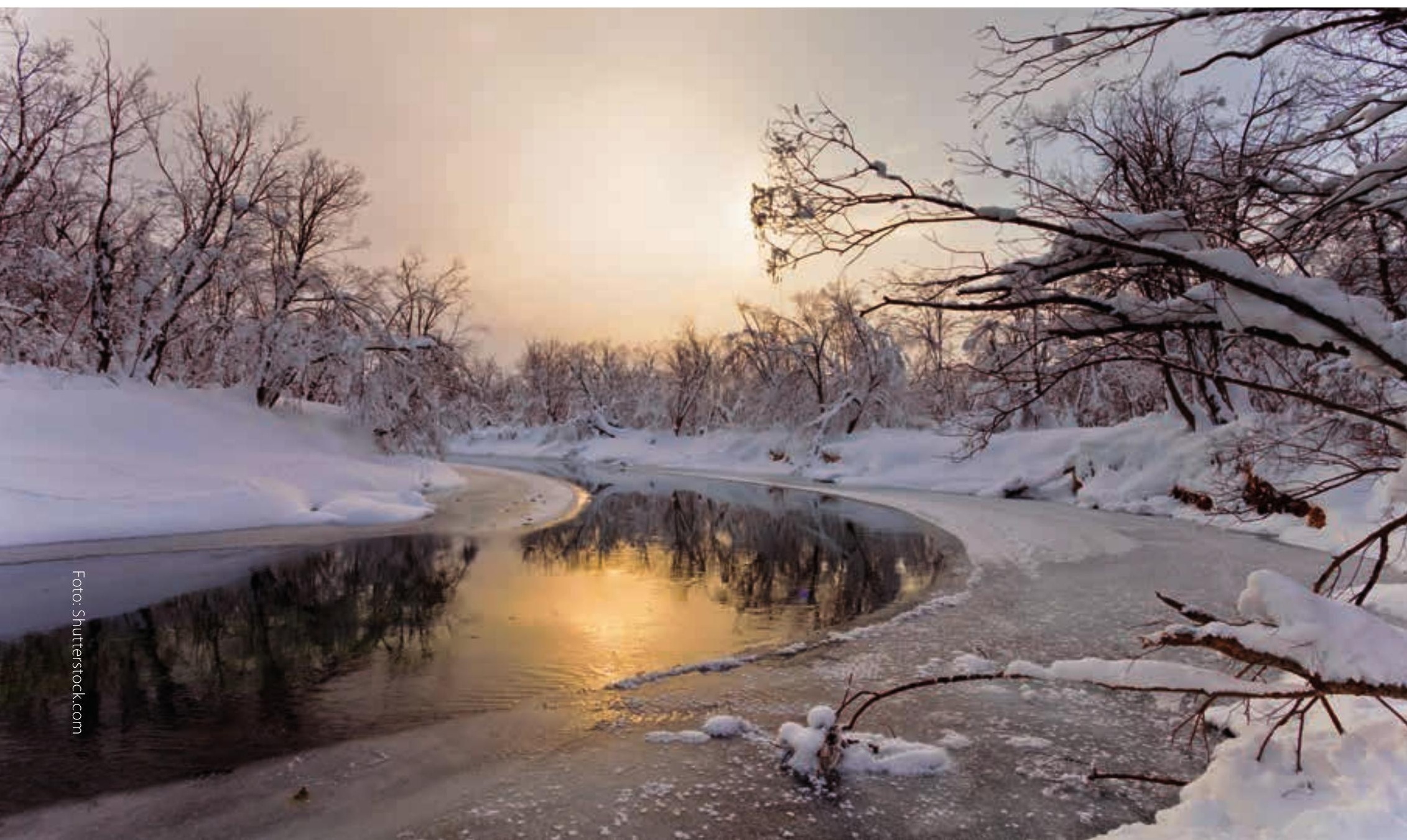

